\title{
The concept of POSER (Plankton Observation with Simultaneous Enclosures in Rosfjorden)
}

\author{
U. H. Brockmann" ${ }^{1}$ E. Dahl ${ }^{2}$, J. Kuiper ${ }^{3}$ and G. Kattner ${ }^{1}$ \\ ${ }^{1}$ Institut für Organische Chemie und Biochemie, SFB 94, Universität Hamburg, Martin-Luther-King-Platz 6. \\ D-2000 Hamburg 13, Federal Republic of Germany \\ ${ }^{2}$ Statens Biologiske Stasjon Fledevigen, N-4800 Arendal, Norway \\ ${ }^{3}$ Laboratory for Applied Marine Research, Division of Technology for Society MT-TNO, P. O. Box 57, 1780 AB Den Helder, \\ The Netherlands
}

\begin{abstract}
Enclosures with diameters of 0.75 and $1.0 \mathrm{~m}$ and depths to $40 \mathrm{~m}$ were used to investigate the phytoplankton spring bloom in southern Norway. Development of natural plankton populations was analyzed in parallel experiments supplemented by monocultures of the main phytoplankton species and in pollution experiments using mercury and Ekofisk oil. A brief account is presented of preinvestigations and enclosure design, and the objectives of POSER are outlined.
\end{abstract}

\section{INTRODUCTION}

Enclosure experiments have been developed to an important tool in aquatic ecosystem research; they serve as a bridge between laboratory experiments and field investigations. The different systems have been reviewed by Kinne (1976), Zeitzschel (1978), Menzel and Steele (1978), Davies and Gamble (1979) and Grice and Reeve (1982). Exclusion of advection of water masses enables sampling of the same water column over longer periods; this is of great advantage, for example, when studying metabolic processes of marine plankton communities.

If the bags are filled within a short time with water from the same water mass, the ecosystems in different enclosures develop similarly when exposed to the same environmental conditions (Takahashi et al., 1975; Brockmann et al., 1977b; Kuiper, 1977a). It has also been shown that the systems in the bags develop in many respects similar to the surrounding plankton community (Takahashi et al., 1975). Enclosure experiments have proven to be a valuable tool for investigating interactions between plankton populations, and those between plankton and chemical environment, including effects of sublethal concentrations of dissolved pollutants.

Major aims of enclosure experiments and specific ecological questions in relation to the use of marine mesocosms were considered at the symposium on enclosed marine experimental ecosystems, August 1980, at the CEPEX-site (Grice and Reeve, 1982).

\section{ENCLOSURE DESIGN}

In comparison to other enclosure systems recently used in marine plankton research, our system is very simple. Our enclosures are free-floating plastic bags, mostly comparable to the Loch Ewe (Davies and Gamble, 1979) and CEPEX enclosures (Menzel and Case, 1977; Grice et al., 1980). In comparison to those systems our enclosures have the following advantages:

(1) Bags with a diameter of only 0.75 or $1 \mathrm{~m}$ make launching very easy (no divers, counter-weight systems [CEPEX] or guide constructions, i.e. Loch Ewe). The bags are filled by a pump or by raising them to the surface. The water can be enclosed quickly.

(2) Simple mounting system consisting only of ringframes to which the plastic foil is fastened by a textile band (Fig. 1) (Brockmann et al., 1974).

(3) Low costs of hardware due to using manufactured, seamless plastic tubes without special adaptions except for cutting and closing. In this way, always new, clean plastic can be used and problems of enclosure cleaning are avoided.

(4) Seamless tubes of 2 layers of plastic: $100 \mu \mathrm{m}$ polyethylen (inside) and $30 \mu \mathrm{m}$ polyamide (outside) (Brockmann et al., 1974). This renders our enclosure 
material physiologically inert and impermeable to gases and trace metals.

(5) The small diameter ensures that sampling of a few liters is representative for the chosen depth, because horizontal patchiness - as observed in large CEPEX-enclosures (Takahashi et al., 1975; Grice et al., 1977) - is unlikely. Although square dimensions exposed to wave action are small, a representative surface of the water column could be maintained. This is in contrast to enclosure constructions with a straightened top as developed by Strickland and Terhune (1961) and Gamble et al. (1977) and to enclosures fixed to the bottom of the Kiel Plankton Tower (von Bodungen et al., 1976).

(6) By using thin, translucent plastic foil, light will be reduced to about $10 \%$ (Brockmann et al., 1974) and turbulence from outside will be transferred to the enclosed water column if this column is kept in water of nearly the same density.

(7) Next to smaller bags we used enclosures with depths of $40 \mathrm{~m}$ at the Rosfjord test site - a deep basin without tidal currents. These are the deepest enclosures that have ever been used. They allowed the inclusion not only of the euphotic zone, but also very often of a pycnocline acting as a natural boundary.

There are also some disadvantages to our system:

(1) While the 2-layer-foil is much more resistant to mechanical forces than simple polyethylene foil or lattice-strengthened material, it may also be damaged in free-floating frames (Fig. 1) after several hours of exposure to high wind-generated waves $(>1 \mathrm{~m})$ or strong currents $\left(>15 \mathrm{~cm} \mathrm{~s}^{-1}\right)$. At sheltered locations, we had no problems with wave forces even during gales with wind velocities of more than $20 \mathrm{~m} \mathrm{~s}^{-1}$ (Brockmann et al., 1981a). Significant changes in water densities caused the problems typical for long enclosures: collapsing at the surface in lighter water or swimming up in water with increased density. Experiments in the open sea (as performed in 1982 in the North Sea for $10 \mathrm{~d}$ ), or at locations not so sheltered, may therefore be limited in time by hydrodynamic forces. Hence, our system is not optimal for long-term experiments (several mo) investigating developmental cycles of larger animals.

(2) The small diameter of the enclosures also limits the representative development of animals of trophic levels higher than carnivorous zooplankton (Kuiper, 1982) as well as frequent zooplankton sampling by nets. Further, the smaller volume/wall ratio exerts more influence on wall-attached organisms in the enclosed ecosystems.

Measurements in unpolluted controls are necessary to study the effects of pollutants. Therefore, it is practical to combine basic research with pollution experiments. This was one of the reasons for performing Plankton Observation with Simultaneous Enclosures in Rosfjorden (POSER), 1979. Along with intensive investigations of natural plankton populations as well as of mono-specific diatom cultures, the influence of crude oil and mercury on plankton development was analyzed.

For the first time experiments were run with monocultures of dominant phytoplankton species in enclosures parallel to enclosed complex natural plankton ecosystems, including those species for studying separate processes in more detail. Since we are primarily interested in interactions between microheterotrophs phytoplankton and herbivorous zooplankton - and chemical properties of their environment, we used the advantages of the very simple plastic tubes.

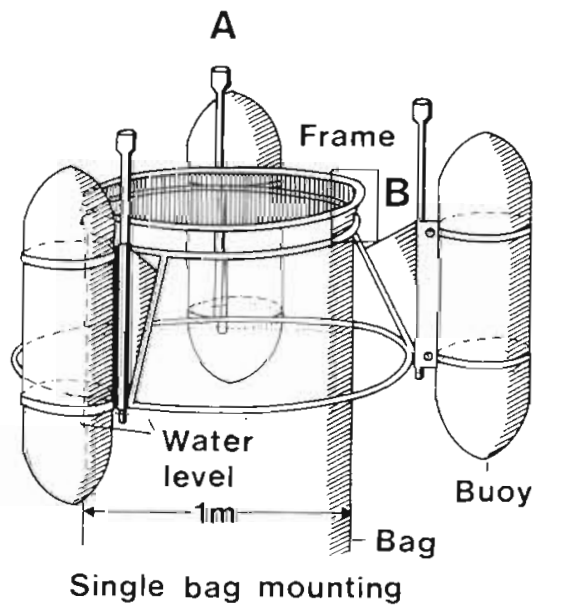

B

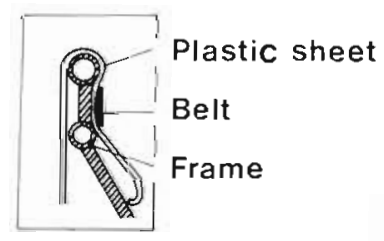

Frame cross section
Fig. 1 Single bag mounting. The flexible plastic bag is fastened to an aluminum ring floated by 3 buoys (A). Bag fixing to frame by a belt is shown in cross section (B). Two aluminum rings are connected by an aluminum web form-

ing a groove for the belt 


\section{LOCATION AND PRE-INVESTIGATIONS}

The southern coast of Norway was chosen as study site because of the amphidromic conditions in this area which minimize water exchange due to tidal currents, and the presence of deep, open fjords (Fig. 2). Rosfjorden, with a sill at about $70 \mathrm{~m}$ depth (Fig. 3), is unpolluted and has only small fresh-water influxes; hence

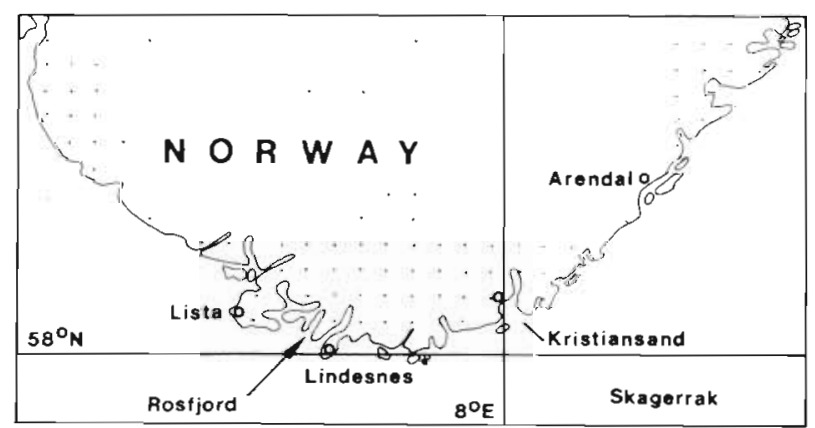

Fig. 2. Location of Rosfjorden in southern Norway

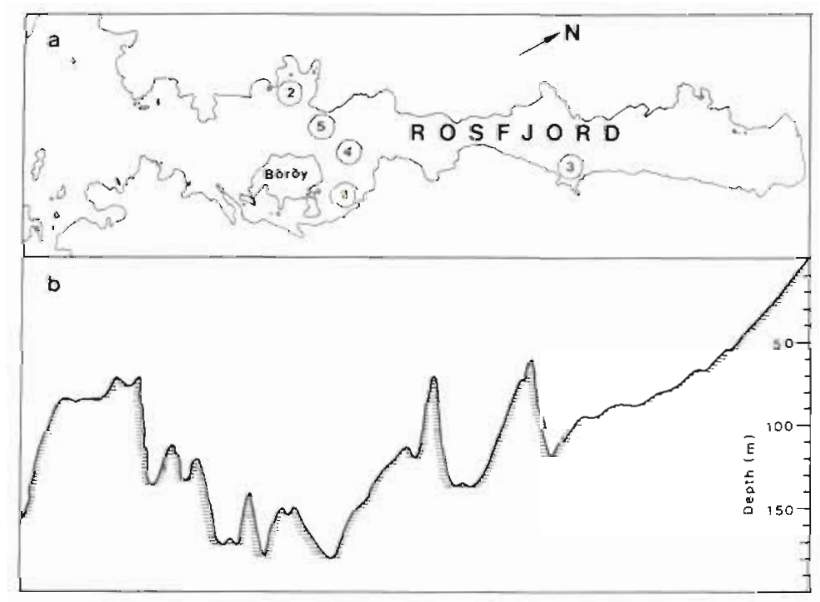

Fig. 3. Rosfjorden. (a) Map with stations of pre-investigations; (b) bottom profile (means for 2 cruises)

the fjord water, with a salinity range between $S=29$ and 35 , can be assumed to be representative of the North Sea region.

In preliminary investigations during October 1977 , salinity was measured by switch-gear probe at Positions 1 to 3 (depth profiles to $25 \mathrm{~m}$ ) and during April 1978, across a section from Station 1 to 2 (Fig. 4). At all stations below $5 \mathrm{~m}$ we found salinities of more than $\mathrm{S}=30$. Salinities below $\mathrm{S}=30$ were only found at the very surface near the mouths of creeks (Station 3).

Daily salinity measurements at Station 1 from April 22 to 27 revealed an upwelling of saline water from 45 to $25 \mathrm{~m}$ (Fig. 5), a process which occurred several times during the following POSER experiment in 1979 (Brockmann et al., 1981a). At this time the phytoplank-

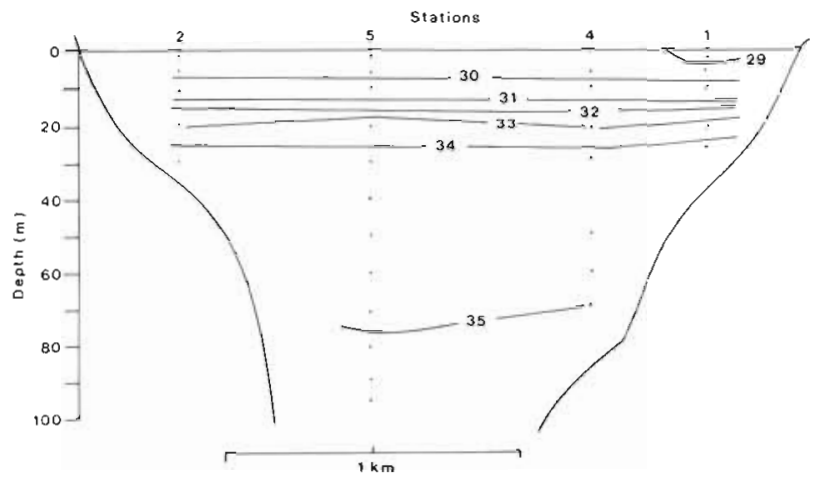

Fig. 4. Salinities at a cross section of Rosf jorden (Stations 1, 4, 5, 2 of Fig. 3) on 24 April 1978. Location of sampling indicated by points

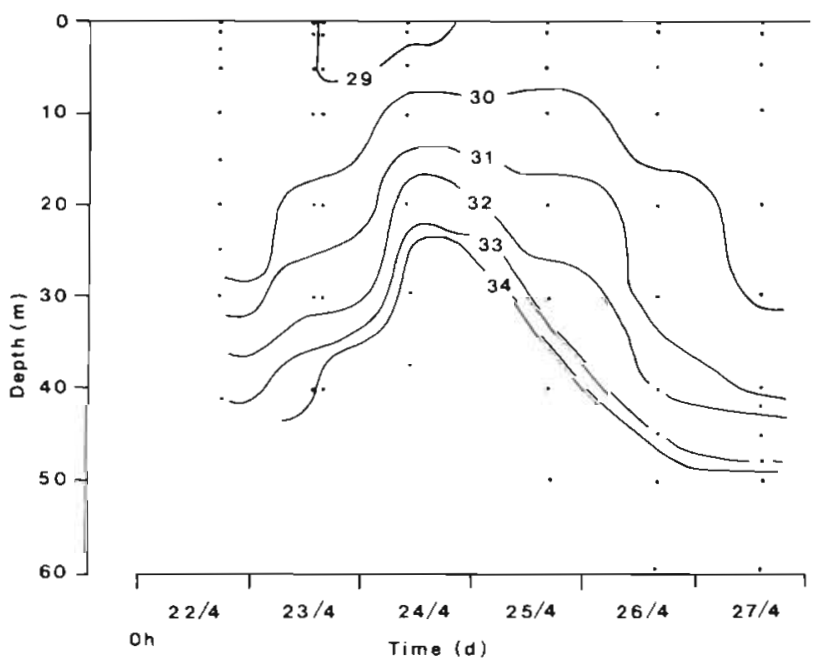

Fig. 5. Change in salinity in Böröy Bight (Station 1, Fig. 3) during April 1978. Time and depths of sampling indicated by points

ton consisted of diatoms, with Skeletonema costatum as dominant species within the haline water (for methods see Kattner et al., 1983). In the upper layer, with very low orthophosphate concentrations (below $0.05 \mu \mathrm{g}$ at $\mathrm{P} \mathrm{dm}^{-3}$ ), various Protoperidinium species, Acartia clausii and Calanus finmarchicus were abundant.

For a longer period during spring 1978, phytoplankton samples were taken near the surface and at $2 \mathrm{~m}$ depth in Böröy Bight (near Station 1) together with measurements of temperature and salinity. These measurements revealed a significant increase in temperature during early April, starting from 2 to $3{ }^{\circ} \mathrm{C}$ and attaining more than $12^{\circ} \mathrm{C}$ at the end of May (Fig. 6). In the upper $2 \mathrm{~m}$ monitored, the salinity fluctuated from $\mathrm{S}=22.5$ to 30 , due to a nearby influx of freshwater. According to phytoplankton counts, the spring-bloom maximum occurred during late March, consisting 


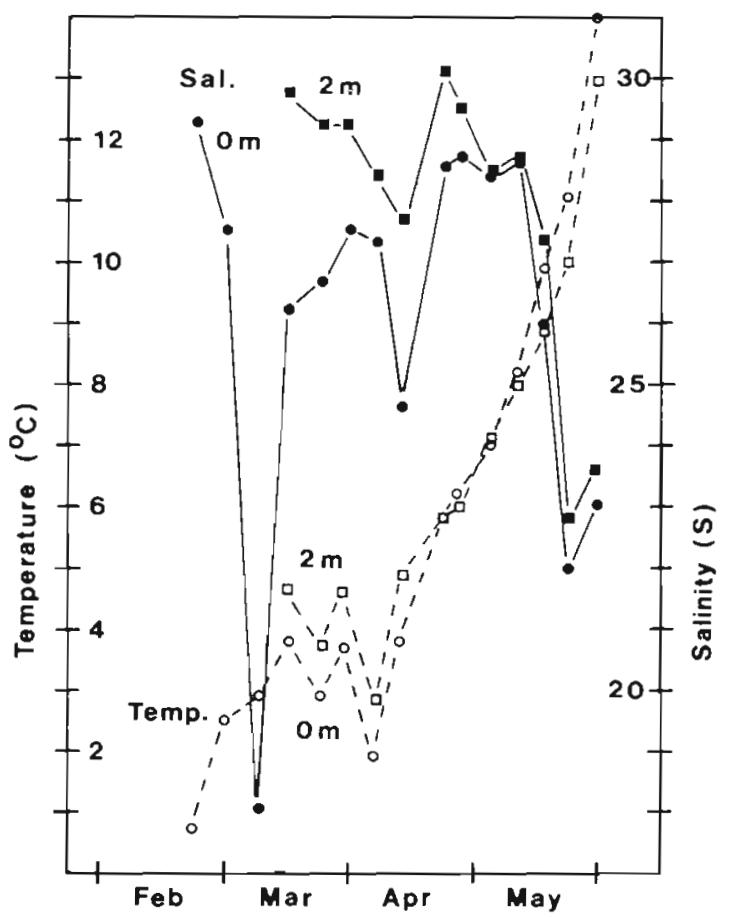

Fig. 6. Salinity and temperature at beach of Böröy Bight during spring 1978

mainly of diatoms, with Skeletonema costatum as dominant species (Fig. 7).

Since the spring bloom had already started around the middle of March, we decided to initiate the POSER experiment the following year at the end of February in order to investigate the phytoplankton spring bloom as the dominating process. It was hoped that interactions between different ecosystem components could be recognized better due to the dominance of only a few processes such as phytoplankton growth, nutrient uptake and release of dissolved organic substances by phytoplankton which is followed by nutrient limitation, change in phytoplankton metabolism (Hammer et al., 1981; Brockmann et al., 1983), sedimentation and zooplankton growth.

\section{STATION}

At the site of pre-investigation (Station 1, Fig. 3) the station with enclosures was anchored at a water depth of 60 to $80 \mathrm{~m}$ in the Böröy Bight of Rosfjorden (Fig. 8). A central float ('Ringstation') and single holding devices were connected by ropes below the water surface. This system was fixed within an array of 4 connected buoys moored by 4 stones. By this construction, without verti-

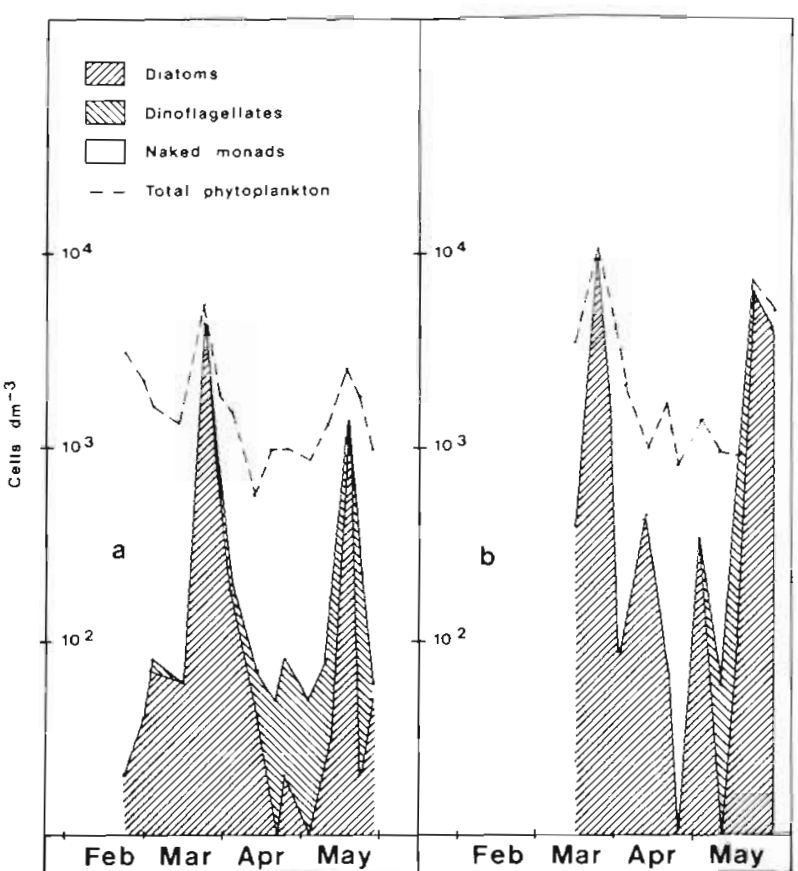

Fig. 7. Phytoplankton development in Böröy Bight during spring 1978. (a) surface; (b) $2 \mathrm{~m}$ depth

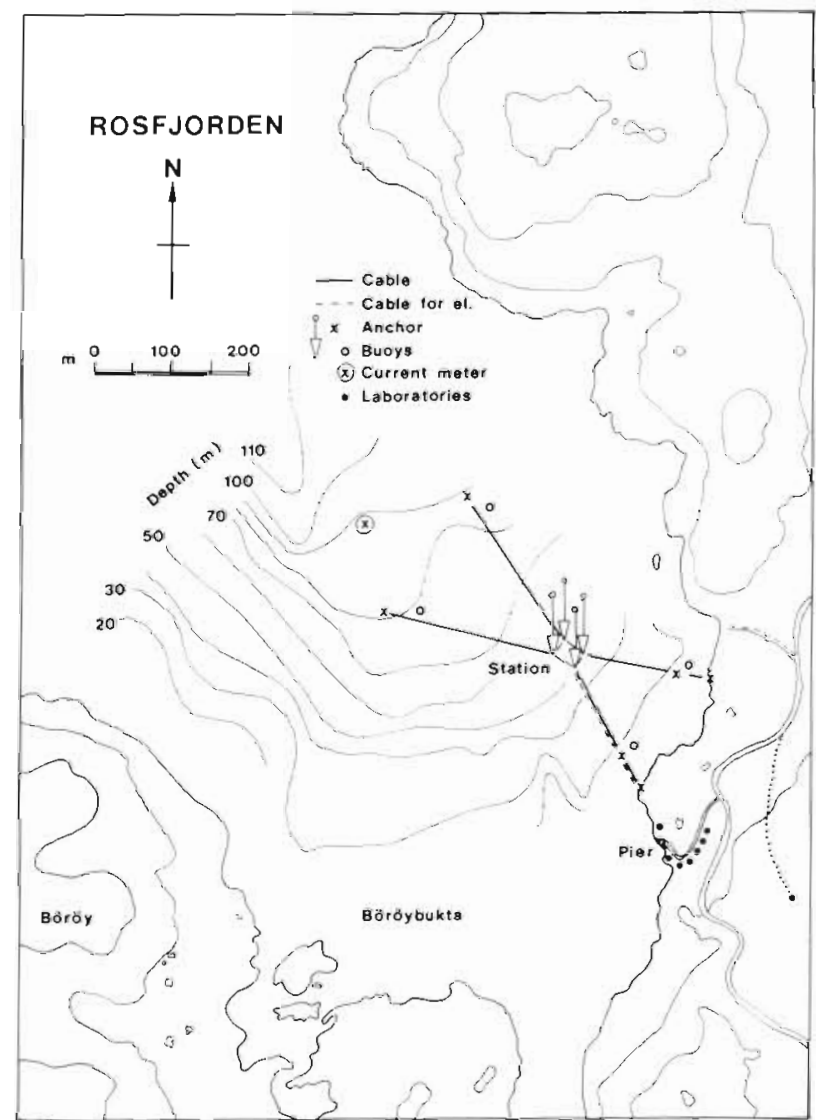

Fig. 8. Map of POSER site: Böröy Bight in Rosfjorden, southern Norway 
cal cables (Fig. 8 and 9), bag damage by anchor cables was avoided; $6 \mathrm{~mm}$ nylon ropes and $4 \mathrm{~mm}$ wire cables to the shore were fixed to $1000 \mathrm{~kg}$ stones by $8 \mathrm{~m}$ long chains, thus avoiding grating of the cables. The anchoring system was designed by Blendermann and Gerlach (1979) to withstand stresses caused by a fetch of $2 \mathrm{~km}$ and wind forces up to $20 \mathrm{~m} \mathrm{~s}^{-1}$.

This anchoring system was stable in spite of wind forces of up to $10 \mathrm{Bft}$ and currents of more than $20 \mathrm{~cm} \mathrm{~s}^{-1}$. But the bags, kept in vertical position by weights fixed to the bottom, were damaged once by currents running continuously for several hours caused by a rapid exchange of water masses along the coast (Brockmann et al., 1981a).

The central float, a ring of $6 \mathrm{~m}$ diameter (Fig. 10), consisted of a floating ring with boxes for recorder and printer. A $2 \mathrm{~m}$ high aluminum frame was fastened to this ring. Within the station, 3 bags were hung from the upper frame. The other bag mountings were kept afloat by 3 buoys for each bag, connected to collars $0.5 \mathrm{~m}$ above the water surface (Fig. 1). Thus, waves moved the flexible plastic walls and induced turbulence in the enclosures. This system has been used since 1972 (Brockmann et al., 1974; Kuiper, 1977a).
Fig. 9. Anchoring of POSER station. Station with single bag mountings and ring station are fixed within an array of buoys by ropes below the water surface rendering crossing by flat boats possible. Cable connections to the station on shore were used for data and power transfer
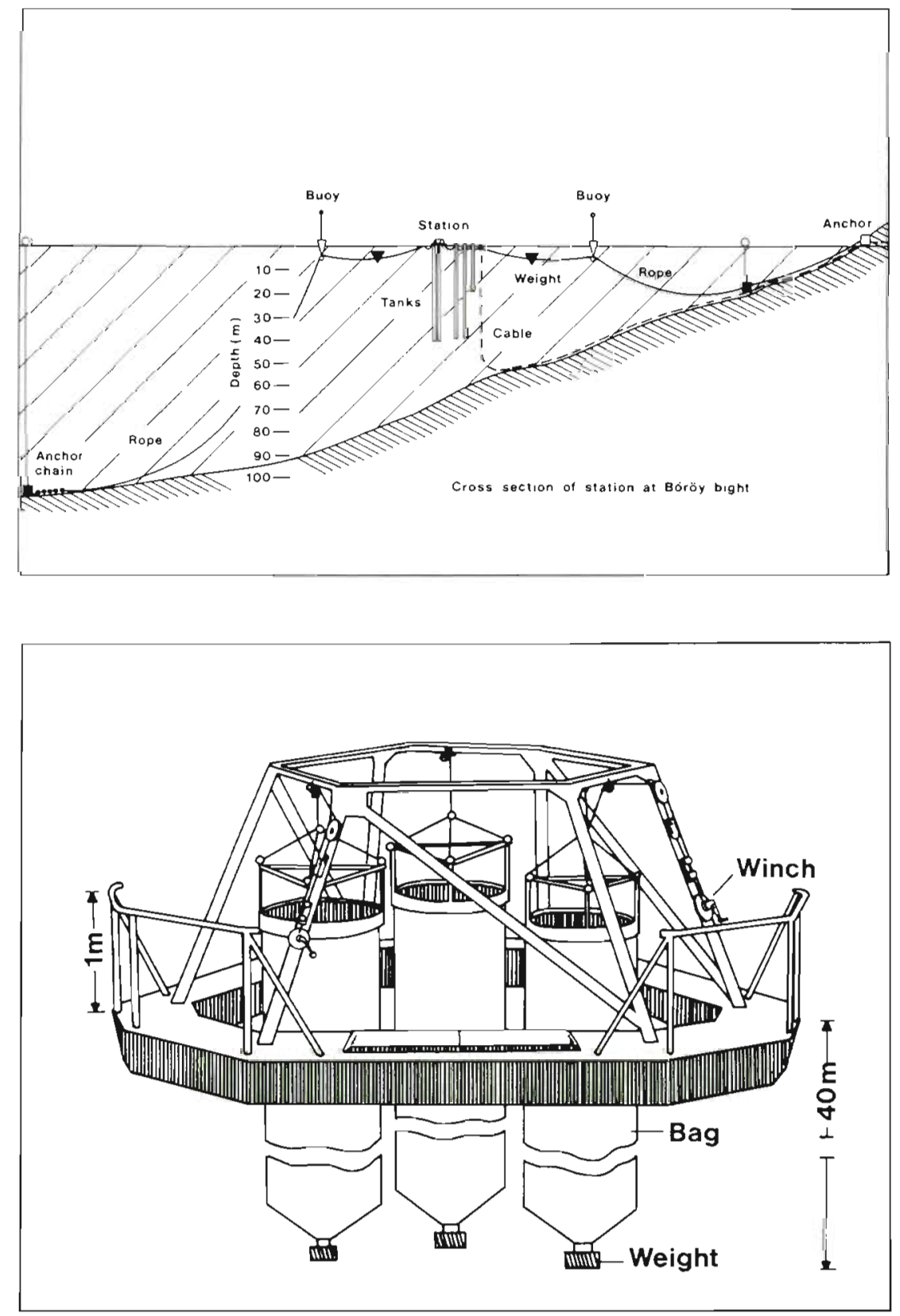

Fig. 10. Ring station. A glass-fiber plastic ring is equipped with an aluminum trestle for сагуying 3 bags 


\section{NATURAL PLANKTON POPULATIONS}

The main aims of the investigations with natural plankton populations were to gain information on aspects of a phytoplankton spring bloom such as: (1) succession of plankton species in connection with succession of inducing factors; (2) release of dissolved organic substances during plankton development; (3) fluxes of material (as elements) between the different trophic levels of the plankton community: (4) diurnal changes in plankton metabolism.

For such research, enclosure of water bodies provides a valuable aid, as the analysis mostly involves measurements of concentration changes in dissolved and particulate matter. The relatively large volume of enclosures permits frequent sampling, e.g. for observations of daily, light-dependent changes, as well as the removal of relatively large samples for analysis of numerous parameters, including trace substances such as dissolved organic matter. These substances play an important role in marine ecosystems, since they have multiple key functions as substrates, growth and inhibition factors and chelators. Analyses of these substances were given much attention during the experiments. Hydrodynamic movements of patchily distributed material in the open sea would obviously complicate such investigations.

On a laboratory scale it is very difficult to simulate natural conditions. Plankton successions can be investigated only in simple, artificially combined systems (Elbrächter, 1976; Kayser, 1979). Frequent analysis of trace substances is limited by the small volume available. In any case, the results must be evaluated critically with regard to their validity for natural systems.

Since release of dissolved organic substances, such as amino acids and carbohydrates, is dependent on plankton and nutrient concentrations (Brockmann et al., 1979; Hammer and Eberlein, 1981), laboratory experiments seem to be more suitable for systematic investigations in this context. Also, laboratory-scale investigations of material fluxes can be performed only with food chains composed of a few components. The diurnal metabolic changes of single plankton species can be analyzed quite precisely in vitro; but only where natural light conditions are established can these results be applied to a natural environment.

Investigations of interactions between numerous parameters in a natural plankton population are facilitated by a 'chromatographic effect' of the enclosed water column. This means that concentration changes in metabolites released from plankton organisms which vertically are distributed inhomogeneously (e.g. motile organisms) can be distinguished from metabolites of homogeneously distributed plankton organisms (Brockmann et al., 1977a). Due to exclusion of horizon- tal diffusion and shift of different water bodies in stratified water, enclosure causes a significant simplification in comparison to the situation in the open water. To investigate the chromatographic effects of density gradients, very deep enclosures with depths of $40 \mathrm{~m}$ have been used. Thus, the entire euphotic zone could be included and effects of salinity and temperature stratification could be observed in some experiments.

A central float was used for filling the large bags with natural plankton. The bags were prepared from rolled-up tubes by closing the bottom, which was weighed with about 10 to $20 \mathrm{~kg}$, to keep the bags in a vertical position. For filling, the collapsed tubes were drawn into the water by the weights. The bags were fastened to aluminum collars, each kept in place by 3 short lines (Fig. 10). The bags were lowered until the collars reached a depth corresponding to the length of a bag. By raising the bags using a winch on the ring station the bags were filled, thus maintaining the stratification of the water column prevailing in the fjord. The small bags were filled according to Kuiper (1981).

\section{PHYTOPLANKTON MONOCULTURES}

In addition to observations of natural mixed plankton systems, some of the dominant phytoplankton species occurring in the fjord were isolated and cultivated. They were inoculated into enclosures filled with filtered and nutrient-enriched sea water in order to obtain information on growth rates in the absence of grazing, on daily nutrient uptake cycles, and on release of dissolved organic substances of single species growing at conditions similar as in the fjord. These experiments had the objective of isolating dominant processes from the complex ecosystem while retaining comparable conditions so that the results could be employed in the ecosystem analysis envisaged.

Interspecies interactions of some strains of bacteria marked by resistence to particular antibiotics - were also studied in culture bags. For the first time marine fungi were analyzed during enclosure experiments in order to learn more about their interactions within the planktonic ecosystem.

\section{POLLUTION EXPERIMENTS}

In addition to the study of natural biological interactions, enclosures provide an opportunity for determining fate and effects of sublethal concentrations of pollutants. Such studies are of considerable importance 
since pollution - especially of shelf seas - is increasing and the paucity of ecologically relevant data prevents quantitative estimates of the effects at the ecosystem level (De Kock and Kuiper, 1981).

\section{Oil}

In the North Sea, the intensity of oil exploitation has increased drastically in recent years. During POSER, 2 series of oil pollution experiments were conducted to investigate influences of surface layers of crude Ekofisk-oil on the plankton development in enclosed water columns. In these experiments dissolved organic substances were analyzed in order to follow the emulsification and solution of hydrocarbon derivatives down through the water column.

In enclosure experiments pollution effects due to oil tend to be diminished by adsorption of the (mostly hydrophobic or amphipatic) substances onto the hydrophobic bag walls.

Gordon et al. (1976), Hodson et al. (1977) and Elmgren and Frithsen (1982) have reported significant effects of oil pollution in enclosure experiments. The effects depend on the type of oil inoculated. In POSER experiments, Ekofisk-oil was tested since this oil type is exploited in this region.

\section{Mercury}

In the past, accidents due to mercury have prompted numerous investigations regarding the fate and effects of mercury on marine ecosystems. Mercury was chosen as a model pollutant during POSER because considerable information is available on fate and effects of its compounds in bag experiments.

Kuiper $(1977 b, 1981,1982)$ performed several plastic-bag experiments to study the influence of mercury on North Sea coastal plankton communities. However, since Dutch coastal waters are loaded by pollutants introduced by rivers and dumping, accumulating effects could not be excluded. To estimate the ecological significance of Kuiper's results it was necessary to repeat his experiments in nearly unpolluted waters. We have further investigated the influence of different nutrient concentrations on pollution effects.

\section{ENCLOSURES OF DIFFERENT SIZE}

Enclosure dimensions are of particular significance. Dutch and German investigators have used relatively small bags (1.5 and $4 \mathrm{~m}^{3}$, respectively). Nevertheless, results obtained with these small enclosures were similar to those produced with the larger bags employed during CEPEX (contents $1300 \mathrm{~m}^{3}$ ) and by Scottish colleagues (Davies and Gamble, 1979). Enclosures of different sizes were used during POSER in order to investigate the influence of bag dimensions on plankton development.

As shown by previous experiments, small copepods developed continuously even in bags with a diameter of only 0.75 and $1 \mathrm{~m}$ (Kuiper 1977a, b; Brockmann et al., in prep.), as did some larger carnivores such as ctenophores (Kuiper, 1982). In addition, small bags have the advantage that horizontal gradients are practically absent, so that single samples can be considered representative for the depths chosen.

Thus far, only a few results from the POSER-experiment have been published (Brockmann etal., 1981a, b). As a follow-up of the papers presented in this issue of MEPS, analyses of material fluxes and of diurnal activities will be published later.

Acknowledgements. We thank T. Belland and S. Euteneuer for assistance. This work was supported in part by 'Deutsche Forschungsgemeinschaft' ('Sonderforschungsbereich 94' Marine Research - Hamburg).

\section{LITERATURE CITED}

Blendermann, W., Gerlach, E. (1979). Vierpunktverankerung für Folientankexperimente. Institut für Schiffbau der Universität Hamburg, Schrift Nr. 2315: 14-25

von Bodungen, B., von Bröckel, K., Smetacek, V., Zeitzschel, B. (1976). The plankton tower. I. A structure to study water/sediment interactions in enclosed water columns. Mar. Biol. 34 : 369-372

Brockmann, U. H., Eberlein, K., Junge, H. D., Trageser, H., Trahms, K. J. (1974). Einfache Foljentanks zur Planktonuntersuchung in situ. Mar. Biol. 24: 163-166

Brockmann, U. H., Eberlein, K., Hosumbek, P., Trageser, H., Maier-Reimer, E., Schöne, H. K., Junge, H. D. (1977a). The development of a natural plankton population in an outdoor tank with nutrient-poor sea water. I. Phytoplankton succession. Mar. Biol. 43: 1-17

Brockmann, U. H., Eberlein, K., Hentzschel, G., Schöne, H. K. Siebers, D., Wandschneider, K., Weber, A. (1977b). Parallel plastic tank experiments with cultures of marine diatoms. Helgoländer wiss. Meeresunters. 30: 201-216

Brockmann, U. H., Eberlein, K., Junge, H. D., Maier-Reimer, E., Siebers, D. (1979). The development of a natural plankton population in an outdoor tank with nutrient-poor sea water. II. Changes in dissolved carbohydrates and amino acids. Mar. Ecol. Prog. Ser. 1: 283-291

Brockmann, U. H., Koltermann, K. P., Dahl, E., Dahle, A., Eberlein, K., Gaertner, A., Gassmann, G., Hammer, K. D., Jahnke, J., Kattner, G., Krause, M., Kuiper, J., Laake, M., Nagel, K. (1981a). Water exchange in Rosfjorden during spring '79, a detailed account of physical, chemical and biological variations. In: Saetre, R., Mork, M. (ed.) The Norwegian coastal current, Vol. 1. University Bergen, p. 93-130 
Brockmann, U. H., Kattner, G., Dahl, E. (1981b). Plankton spring development in a south Norwegian fjord. In: Grice, G. D., Reeve, M. R. (ed.) Marine mesocosms. Springer, New York, p. 195-204

Brockmann, U., Ittekkot, V., Kattner, G., Eberlein, K., Hammer, K. D. (1983). Release of dissolved organic substances in the course of phytoplankton blooms. In: Sundermann, J., Lenz, W. (ed.) North Sea dynamics. Springer, Berlin, p. $530-548$

Davies, J. M., Gamble, J. C. (1979). Experiments with large enclosed ecosystems. Phil. Trans. R. Soc. Lond. B 286: $523-544$

De Kock, W. C., Kuiper, J. (1981). Possibilities for marine pollution research at the ecosystem level. Chemosphere 10: $575-603$

Elbrächter, M. (1976). Population dynamic studies on phytoplankton cultures. Mar. Biol. 35: 201-209

Elmgren, R., Frithsen, J. B. (1982). The use of experimental ecosystems for evaluating the environmental impact of pollutants: a comparison of an oil spill in the Baltic Sea and two long-term, low-level oil addition experiments. In: Grice, G. D., Reeve, M. R. (ed.) Marine mesocosms. Springer, New York, p. 153-165

Gamble, J. C., Davies, J. M., Steele, J. H. (1977). Loch Ewe bag experiment, 1974. Bull. mar. Sci. 27: 146-175

Gordon, D. C., Jr., Keizer, P. D., Hardstaff, W. R., Aldous, D. G. (1976). Fate of crude oil spilled on seawater contained in outdoor tanks. Environ. Sci. Technol. 10: 580-585

Grice, G. D., Reeve, M. R., Koeller, P., Menzel, D. W. (1977). The use of large volume, transparent, enclosed sea-surface water columns in the study of stress on plankton ecosystems. Helgoländer wiss. Meeresunters. 30: 118-133

Grice, G., Harris, R. P., Reeve, M. R., Heinbokel, J. F., Davis, C. O. (1980). Large scale enclosed water column ecosystem. An overview of Foodweb I, the final CEPEX experiment. J. mar. biol. Ass. U.K. 60: 401-414

Grice, G. D., Reeve, M. R. (1982). Introduction and description of experimental ecosystems. In: Grice, G. D., Reeve, M. R. (ed.) Marine mesocosms. Springer, New York, p. 12-19

Hammer, K. D., Brockmann, U. H., Kattner, G. (1981). Release of dissolved free amino acids during a bloom of Thalassiosira rotula. Kieler Meeresforsch., Sonderh. 5: 101-109

Hammer, K. D., Eberlein, K. (1981). Parallel experiments with Thalassiosira rotula in outdoor plastic tanks. Development of dissolved free amino acids during an algae bloom. Mar. Chem. 10: 533-544

Hodson, R. E., Azam, F., Lee, R. F. (1977). Effects of four oils on marine bacterial populations: Controlled ecosystem pollution experiment. Bull. mar. Sci. 27: 119-126

Kattner, G., Hammer, K. D., Eberlein, K., Brockmann, U. H., Jahnke, J., Krause, M. (1983). Nutrient and plankton development in Rosfjorden and enclosed ecosystems captured from changing water bodies during POSER. Mar. Ecol. Prog. Ser, 14: 29-43

Kayser, H. (1979). Growth interactions between marine dinoflagellates in multispecies culture experiments. Mar. Biol. 52: $357-369$

Kinne, O. (1976). Cultivation of marine organisms: waterquality management and technology. In: Kinne, O. (ed.) Marine ecology, Vol. III, Cultivation, Part 1, Wiley, Chichester, p. 19-300

Kuiper, J. (1977a). Development of North Sea coastal plankton communities in separate plastic bags under identical conditions. Mar. Biol. 44: 97-107

Kuiper, J. (1977b). An experimental approach in studying the influence of mercury on a North Sea coastal plankton community. Helgoländer wiss. Meeresunters. 30: 652-665

Kuiper, J. (1981). Fate and effects of mercury in marine plankton communities in experimental enclosures. Ecotoxicol. environ. Saf. 5: 106-134

Kuiper, J. (1982). The use of enclosed plankton communities in ecotoxicology. Thesis, Wageningen

Menzel, D. W., Case, J. (1977). Concept and design: controlled ecosystem pollution experiment. Bull. mar. Sci. 27: 1-7

Menzel, D. W., Steele, J. H. (1978). The application of plastic enclosures to the study of pelagic marine biota. In: PaIsons, T. R., Jansson, B.-O., Longhurst, A. R., SaetersdaI, G. (ed.) Marine ecosystems and fisheries aceanography. Rapp. P.-v. Réun Cons. int. Explor. Mer 173: 7-12

Strickland, J. D. H., Terhune, L. D. B. (1961). The study of in situ marine photosynthesis using a large plastic bag. Limnol. Oceanogr. 6: 93-96

Takahashi, M., Thomas, W. H., Seibert, D. L. R., Beers, J., Koeller, P., Parsons, T. R. (1975). The replication of biological events in enclosed water columns. Arch. Hydrobiol. 1: $5-23$

Zeitzschel, B. (1978). Controlled environment experiments in pollution studies. Ocean Mgmt 4: 319-344 